\title{
Emotional Intelligence and Self-efficacy as Predictor Factors of Student Resilience in Online Learning during Pandemic Era
}

\author{
Nur Ainiyah, Chilyatiz Zahroh (D, Khamida Khamida®D, Syidatul Budury Đ, Siti Nurjanah, Siti Nur Hasina®, Saptita Eka Wardhany \\ Department of Nursing, Faculty of Nursing and Midifery, Universitas Nahdlatul Ulama Surabaya, Surabaya, East Java, Indonesia
}

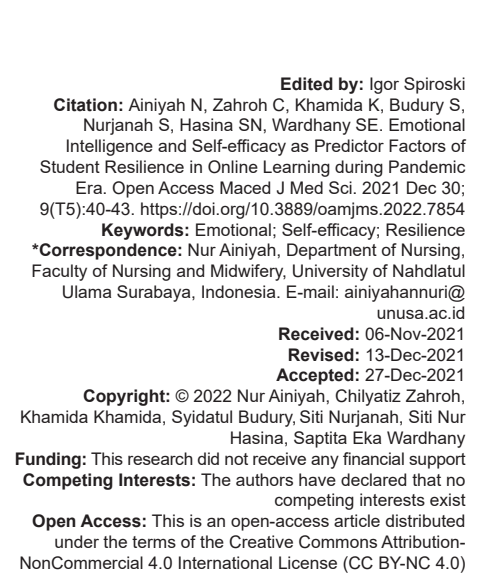

Introduction

COVID-19 began to enter Indonesia in early February 2020. The number of positive cases of the COVID-19 virus in Indonesia increases significantly from day-to-day. COVID-19 positive patients are increasing every day in East Java. The death rate due to COVID-19 in East Java is the highest in Indonesia, in which it reached an additional 43 cases per week per March 28, 2021. This has led to policies including studying from home, doing social distancing, and using masks. This government policy has had a huge impact on the world, especially education, so that in early March 2020, all educational institutions switched to using a bold learning system. Students need to adjust to the learning, but it does not run smoothly like the face-to-face learning process. There are many difficulties encountered by students in carrying out the bold learning process. However, students must be able to adapt and survive with all these difficulties; there are still students who have not been able to adjust to this situation.

The results of the study [1] showed that student resilience was in the medium criteria with a value of $53 \%$, followed by the low criteria of $24 \%$, and high criteria of $23 \%$. The average picture of student resilience in this study is in the medium category, meaning that students are still nervous in dealing with problems during the learning process from home, they are still not able to properly analyze the problem, they still have a low sense of empathy with the surrounding environment but they have high confidence that the pandemic or the problems being faced will be able to be resolved properly, and they have the desire to optimize their abilities to get maximum results [2].

This resilience is influenced by several factors. Internal factors that affect resilience include spirituality, self-efficacy, optimism, and self-esteem, while the external factor that affects resilience is social support [3]. Resilience is very much needed for students because if students have high resilience, they will be able to rise and be able to survive even though they are faced with difficult situations due to the COVID-19 pandemic. The results of research showed that good self-esteem and academic resilience are needed by students to prepare university students in implementing the learning of the higher education [4]. In addition, research results prove that students who have high resilience will be more optimistic and believe that everything can change to be better [5]. 
Based on these two studies, it is clear that resilience is needed by students. Therefore, research is needed concerning the relationship between emotional intelligence and self-efficacy with student resilience in online learning in the pandemic era.

The instruments used in this study were the emotional intelligence questionnaire, general selfefficacy scale, and brief resilience scale. The emotional intelligence scale consisted of 34 items to measure emotional intelligence. This scale consisted of selfawareness, self-regulation, social skill, empathy, and motivation. The brief resilience scale is a 6-items scale that measures perception of health. The data were collected using the Google form.

Table 1: Respondents' characteristics

\begin{tabular}{lll}
\hline Characteristics & $\mathrm{N}$ & $\%$ \\
\hline Age & 33 & \\
18 & 123 & 24.3 \\
19 & 131 & 25.8 \\
20 & 126 & 24.9 \\
21 & 93 & 18.5 \\
22 & 412 & 81.4 \\
Male & 94 & 18.6 \\
Female & 494 & 97.6 \\
Home & 12 & 2.4 \\
Boarding house & & \\
\hline
\end{tabular}

\section{Study design, setting, and sampling}

The study was correlational analytics with a cross-sectional approach. The population was the university students of the nursing department of Nahdlatul Ulama University. The sample was 506 university students selected randomly. The study was conducted in February 2021.

Table 2: The level/degree of emotional intelligence, self-efficacy, and resilience

\begin{tabular}{lll}
\hline Variables & $\mathrm{n}$ & $\%$ \\
\hline Emotional intelligence & & \\
Low & 52 & 10.27 \\
Moderate & 48 & 9.48 \\
$\quad$ High & 406 & 80.25 \\
Self-efficacy & & \\
$\quad$ Low & 48 & 9.48 \\
Moderate & 302 & 59.68 \\
$\quad$ High & 156 & 30.84 \\
Resilience & & \\
Low & 60 & 11.85 \\
Moderate & 81 & 16 \\
High & 365 & 72.15 \\
\hline
\end{tabular}

\section{Study variables}

The dependent variables in this study were emotional intelligence and self-efficacy. The independent variable was the resilience of students in doing online learning.

\section{Data analysis}

The Pearson correlation test was used for statistical analysis

\section{Results}

Table 1 displays the gender, age, and place to stay of nursing students. The sample is representative of undergraduate nursing students. It showed that the respondents were 19 years old $(59.03 \%)$, female $(92.77 \%)$, and staying at home $(71.08 \%)$. Table 2 displays the distribution frequency of nursing students' emotional intelligence, self-efficacy, and resilience. The data showed that students have high emotional intelligence $(80.25 \%)$, moderate self-efficacy $(59.68 \%)$, and high resilience $(72.15 \%)$. Tables 3 and 4 showed the relationship between emotional intelligence, self-efficacy, and resilience. The Spearman's rank correlation test was used to investigate the relationship. The data showed that there was a relationship between emotional intelligence and resilience $(r$ value $=0.815)$ and there was a relationship between self-efficacy and resilience ( $r$ value $=0.546$ ).

Table 3: Correlation between emotional intelligence with student resilience

\begin{tabular}{lll}
\hline Variables & Emotional intelligence & Student resilience \\
\hline Emotional intelligence & 1.000 & $0.815^{\star *}$ \\
Student resilience & & 1.000
\end{tabular}

\section{Discussion}

The study showed that there was a relationship between emotional intelligence and self-efficacy with student resilience in online learning.

Table 4: Correlation between emotional intelligence with student resilience

\begin{tabular}{lll}
\hline Variables & Self-efficacy & Student resilience \\
\hline Self-efficacy & 1.000 & $0.546^{\star *}$ \\
Student resilience & & 1.000 \\
\hline
\end{tabular}

Emotional intelligence in life will have a positive impact on physical health, academic success, ease in building relationships with others, and increasing resilience [6]. The aspect of recognizing emotions from emotional intelligence indirectly affects the insight of an individual. The individual's ability to recognize selfemotions will support the individual for the emotions that he experiences to make decisions.

Goleman showed that applying emotional intelligence in life will have a positive impact on physical health, academic success, ease in building relationships with others, and increasing resilience. Good emotional management is an aspect of emotional 
intelligence that indirectly affects the resilience aspect, namely, creativity. To control emotions, individuals must understand that every action has consequences, both for themselves and others. Individuals that have good resilience do not engage in negative behavior because they can consider the consequences of their behavior and make the right decisions [6].

In the aspect of emotional intelligence, it also recognizes caring for other people's emotions and building relationships related to aspects of resilience including relationships and initiative. Emotional intelligence also refers to the interaction between emotions and cognition, which allow individuals to adapt to their environment [7]. In this study, the most of the respondents have high emotional intelligence so that when respondents have complex problems, it is hoped that they can be open, try to understand and help each other when experiencing difficulties, and share with each other. They can entertain each other, share experiences, motivate each other, and seek the best solution to overcome problems so that a sense of togetherness and kinship can be created.

Goleman (2001) states that several factors influence emotional intelligence including experience, age, gender, and position [8]. Based on the results of this study, it can be understood that women have higher emotional intelligence than men [9]. Women tend to have motherhood, empathy, and use feelings more in acting so that their emotional intelligence is higher. Women are more sensitive to the surrounding environment, able to recognize, and manage emotions than men. If people look at the environment around them, the friendships of girls are also more intimate because they understand each other better than the friendships of boys, so they can strengthen each other when they have problems [10].

Adolescent and adult women can process their own emotions and those of others. At this age, women also begin to need the ability to adapt to the social environment and begin to have the ability to think positively [11].

Students who can think positively will be able to adapt and face the problems that they experience better in the learning process. In this case, seeing the difficulties or obstacles faced by students in following and doing assignments, makes students need the role of resilience. Conditions that are likely to be unpleasant and felt by students will be the basis for students to build resilience that is able to become a basic strength to grow positive characters in building emotional and psychological strengths and increasing individual academic success.

Self-efficacy is related to student resilience in online learning. This is in line with Schoon (2006) who states that the factors that contribute to resilience are individual factors, family characteristics, and social relationships. Self-efficacy is included in individual factors. Other studies also show that resilience and self-efficacy have a close empirical relationship [5].
Self-efficacy can also be used as an individual's desire and ability to continue to find a way out of the problem at hand. Students with the high levels of selfefficacy tend to believe in their abilities and will develop a variety of resilient behavioral responses such as not easily discouraged, diligent, and resilient against various obstacles faced. Whereas if the individual feels lazy because he feels that he is failed, then he is easily discouraged, having a low effort to achieve the goals that have been set and the level of self-efficacy tends to be low. The same thing is known in research which shows that there is a relationship between self-efficacy and resilience of university students who are working on their final project [12].

\section{Conclusion}

The study showed that there was correlation of emotional intelligence and self-efficacy with student resilience in online learning. Improving emotional approaches and self-efficacy can be done by increasing positive coping strategies and give social support.

\section{Ethical Clearance}

The ethical approval for this study was granted by research ethics committee Brahmanda Lentera Institution in 2021: No. 025/14/IV/EC/KEPK/Lemb. Candle/2021

\section{References}

1. Sari SP, Aryansah JE, Sari K. Student resilience in the face of the COVID-19 pandemic and its implications for the learning process. Indones J Guid Couns Theory Appl 2020;9(1):17-22.

2. Kumalasari D, Akmal SZ. Academic resilience and online learning satisfaction during the COVID-19 pandemic: The mediating role of online learning readiness. Pers Psikol Indones. 2020;9(2):353-68. https://doi.org/10.30996/persona.v9i2.4139

3. Missasi V, Izzati ID. Faktor Faktor Yang Mempengaruhi Resiliensi. Prosiding Seminar Nasional Magister Psikologi University of Ahmad Dahlan; 2019. p. 433-41.

4. Sholichah IF, Paulana AN, Putri F. Self-esteem dan Resiliensi Akademik Mahasiswa. Proceeding National Conference Psikologi UMG, No. 2002. p. 191-7; 2018. Available from: http:// journal.umg.ac.id/index.php/proceeding/article/view/920 [Last access 2021 May 28]

5. Schwarzer R, Warner LM. Perceived Self-Efficacy and its Relationship to Resilience. ???: ???; 2013. p. 139-50. https:// doi.org/10.1007/978-1-4614-4939-3_10 
6. Maulding WS, Peters GB, Roberts J, Leonard E, Sparkman L. Emotional intelligence and resilience as predictors of leadership in school administrators. J Leadersh Stud. 2012;5(4):20-30. https://doi.org/10.1002/jls.20240

7. Salavera C, Usán P, Jarie L. Emotional intelligence and social skills on self-efficacy in secondary education students. Are there gender differences? J Adolesc 2017;60:39-46. https://doi. org/10.1016/j.adolescence.2017.07.009

8. Khalili A. The role of emotional intelligence in the workplace: A literature review. Int J Manag 2012;29(3):355-70.

9. Cabello R, Sorrel MA, Fernández-Pinto I, Extremera N, FernándezBerrocal P. Age and gender differences in ability emotional intelligence in adults: A cross-sectional study. Dev Psychol. 2016;52(9):1486-92. https://doi.org/10.1037/dev0000191

PMid:27570984
10. Chow CM, Ruhl H, Buhrmester D. The mediating role of interpersonal competence between adolescents' empathy and friendship quality: A dyadic approach J Adolesc. 2013;36(1):191-200. https://doi.org/10.1016/j. adolescence.2012.10.004

PMid:23176745

11. Ungar $\mathrm{M}$, Theron $\mathrm{L}$. Resilience and mental health: how multisystemic processes contribute to positive outcomes. Lancet Psychiatry. 2020;7(5):441-8. https://doi.org/10.1016/ S2215-0366(19)30434-1

PMid:31806473

12. Mahesti NP, Rustika IM. The role of emotional intelligence and self-efficacy on resilience in Udayana University Students who are Compiling Thesis. J Psikol Udayana. 2020;7(2):53-65. https://doi.org/10.24843/JPU.2020.v07.i02.p06 